\title{
USING PHENOMENOGRAPHY TO UNDERSTAND PATTERNS OF INSTRUCTION IN GROUP WORK
}

\author{
Lyndall Cooper-Smith ${ }^{1}$ and Bill Davey ${ }^{2}$ \\ RMIT University, Melbourne, Australia \\ ${ }^{1} \mathrm{PhD}$ Candidate \\ ${ }^{2} \mathrm{Dr}$.
}

\begin{abstract}
Group work is regularly implemented as part of higher education learning. Much research has examined group work to determine both the impeding and facilitative factors, mostly from the perspective of the students' experiences of group work. To address the negative factors of group work, it would be helpful to understand the perceptions instructors have about group work.

In Australia, prospective employers consistently call for business graduates to be able to demonstrate collaborative teamwork skills as part of their employability skill set. Group work in undergraduate courses is seen as the appropriate mechanism for teamwork education. Collaborative teamwork skills are considered the second most sought after demonstratable skill in a prospective employee; communication skills being the most sought after. How then can universities engender a growth in online group work as a means of ensuring their online undergraduates are being educated to develop their collaborative teamwork skills?

This research examined the perceptions of instructors about their group work experiences. A phenomenographic research approach was considered the most appropriate, as phenomenography allows for all variations of perceptions to be considered, regardless of other factors such as experience or discipline specificity. Phenomenography facilitates the closer examination of a phenomenon, for example, how students learn. By examining the perceptions individual instructors have about their role in group work, patterns of instruction were illuminated.

The findings of the research are expressed as phenomenographic categories of conception. The categories of conception detail the perceptions an instructor has in relation to their pattern of instruction. The categories can be expressed on a continuum of less complex to more complex. The categories do not describe individual instructors, instead all of the instructors' perceptions of group work. By understanding an instructor's perceptions about group work, it is expected that changes in practice can be engendered.
\end{abstract}

\section{KEYWORDS}

Group Work, Online Group Work, Higher Education; Phenomenography, Categories of Conception 


\section{INTRODUCTION}

Group work, is recognised as a learning tool that facilitates collaborative learning (Oliveira et al., 2011), which has been widely adopted in Australian higher education as a tool for learning Baskin et al. (2005), (Koh and Hill, 2009, Friedman and Friedman, 2011, Wilson et al., 2018a), and, is thought of as "an important preparation for professional careers, providing a level of real-world authenticity" (Smith et al., 2011). Group work is defined as two or more individuals, working as individuals and together, to achieve a common goal (Choi and Kang, 2010). Similarly, Riebe et al. (2016) defined teamwork as two or more students interdependently working toward a common goal with personal accountability. Online group work has the potential to optimize student learning (Chang and Kang, 2016).

In education, learning pedagogy points out that knowledge is not simply transmitted from one person to another (An et al., 2008, Hase, 2001), learning is as a result of interaction by acquisition, enquiry, discussion, practice and collaboration (Laurillard, 2012). Whilst in group work, much of the learning occurs in student-to-student interactions with no instructor presence (Davey et al., 2016). "Why then is online group learning not more widely practiced, particularly within higher education?"(Roberts and McInnerney, 2007).

Research has found that the success or otherwise of group work to achieve the learning objectives can be variable (Kavanagh et al., 2010). Much research has focused on the students' perceptions of group work. Research has shown that students are reluctant to engage in online group work because of its' challenges (Chang and Kang, 2016, Roberts and McInnerney, 2007, Barcelona and Rockey, 2010, Smith et al., 2011, Xu et al., 2015, Wilson et al., 2018b). Whereas, limited research studies have investigated the perceptions of in-service instructors about online group work, which has a direct influence on their willingness to offer online group work as a learning tool (An et al., 2008). Or, is there a reluctance to practice online group work as Baskin et al. (2005) argued, because the principles of engagement in online group work are much more complex than in face-to-face group work? By better understanding the perceptions instructors have about group work and why they perceive it to be difficult, or unproductive, instructors can be supported to change their perceptions and their experience of leading and managing group work.

\section{BACKGROUND LITERATURE}

The role of the instructor in online group work cannot be understated, "the efficient conduct of both professional and informal instructor behaviours are necessary for successful learning experiences (Arbaugh, 2008)(p.1243). It can be asserted then that the instructor's role is significant, from the conception of the learning task, managing the formation of the groups, questioning, responding to questions, keeping the groups focused, to grading group presentations. Goold et al. (2010) found that the instructor, because of their discipline expertise, is able to scaffold learning that builds student engagement to promote deep learning. Whereas, Rienties et al. (2013) argued that to be successful in online instruction, the instructor should be a content (discipline) expert, understand learning pedagogy and also be a proficient technology user. More recently, Salmon et al. (2015) advanced the view that there is an urgency for educational institutions to build the capacity of their instructors to "embrace forward-looking learning design" (p.543) for blended, online and mobile learning. 
Laurillard (2012) strongly argued that instructors must resist the notion that technology allows students to do it all themselves. Laurillard (2012) validated this point by asserting that instructors have a more critical role in scaffolding the learning to support students to think and develop their new skills using digital technology. This researcher argued that in a technology-led education environment, it is now time to shift the focus from learning to instruction; quality instruction. The instructor's role is extremely important in creating an environment conducive to collaborative and participative online learning (Oliveira et al., 2011).

Urhahne et al. (2010) researched the role of the instructor in computer-supported collaborative inquiry learning. An outcome of their research was the five principles for the role of the teacher; the 5E Model. The five principles of their 5E Model are: 1) envision the lesson; 2) enable collaboration; 3) encourage students; 4) ensure learning; and, 5) evaluate achievement. These principles span the whole instructional process from planning to assessment (Urhahne et al., 2010). Together, the principles provide a blue-print for the role of the instructor. Each of the Urhahne et al. (2010) principles are summarily outlined:

1) Envision the learning: In this stage the instructor has the role of planner, organiser and decision maker. Course content, software applications, learning tasks, assessment tasks, communication and administrative processes have to be considered and accommodated.

2) Enable collaboration: In this stage the instructor has to ensure the students have the means to collaborate with each other for the facilitation of knowledge exchange. At times the instructor may need to over-ride student-to-student exchanges.

3) Encourage students: In this stage the instructor is not always a silent bystander, their role is to react flexibly to encourage interactions, to clarify and to spark the learning.

4) Ensure learning: In this stage the instructor is ensuring that the discipline-specific knowledge is being learnt by questioning, challenging and offering praise.

5) Evaluate achievement: In the final stage the instructor undertakes assessment and provides feedback. Comparative assessment grades provide the instructor with the means to evaluate their instructional effectiveness.

The 5E Model identifies each of the multifaceted tasks within each of the roles the instructor has in collaborative learning, in fact, there is no stage where the instructor is passive or redundant (Urhahne et al., 2010). The 5E Model attributes an "active, planning, supporting, and evaluating function" to the instructor (Urhahne et al., 2010)(p.240). The Urhahne et al. (2010) research outlines that an instructor has many tasks, hence the $5 \mathrm{E}$ Model is a guide to practice.

Other studies have also sought to identify the role of the instructor in group work. From the research of Young (2006), Arbaugh (2010) and Bigatel et al. (2012) it was claimed that effective online instruction was based on the instructor competence, with social presence and teacher presence being critical factors. In his study, Kraiger (2008) specifically asked: is an instructor implicitly and explicitly aware of their role in group work? One of the key challenges Urhahne et al. (2010) had when attempting to apply the outcomes of their multi-media research into the classroom, was accurately distinguishing the role of the instructor as either teacher, coach, moderator, or decision-maker. Whereas, this research study examined the perceptions of group work instructors, through analysis, their perceptions were compared, contrasted, grouped and expressed as phenomenographic categories of conception. 


\section{THE RESEARCH SPACE}

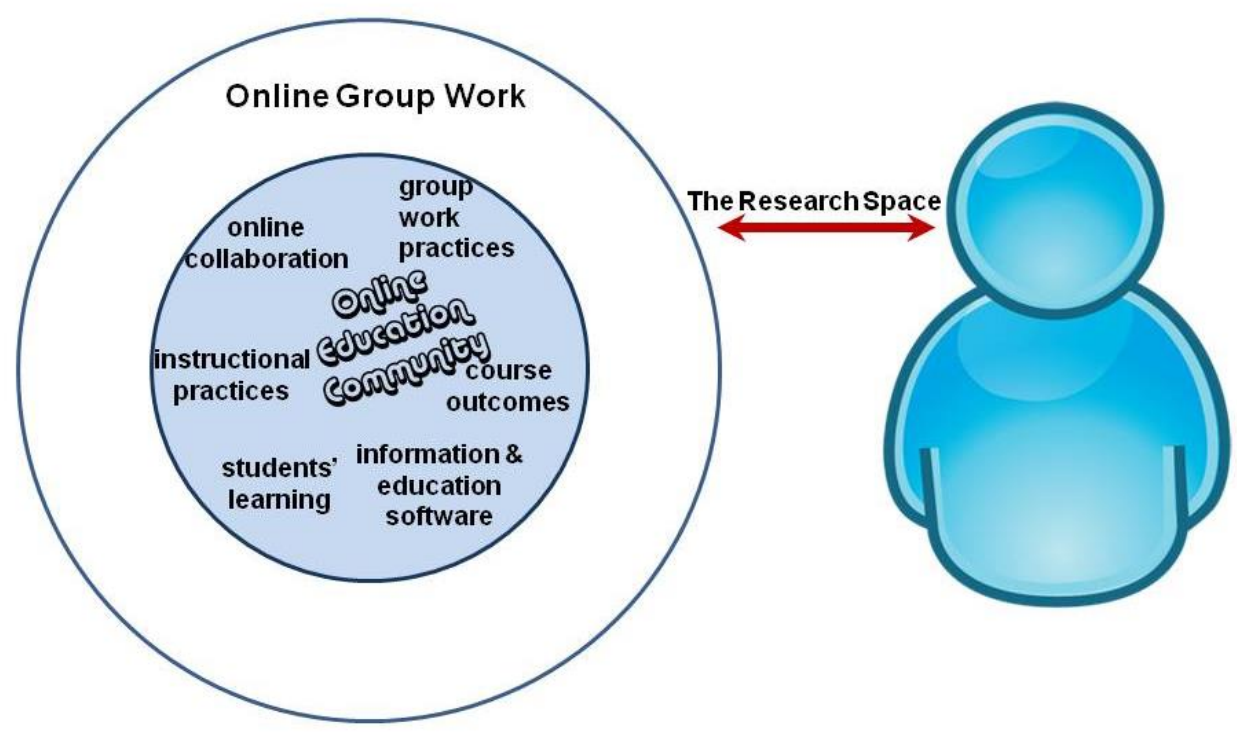

Figure 1. The research space

In Figure: 1, the research space is diagrammatically represented as the instructor's role in offering online group work within a complex virtual learning community environment. This research study is not of group work per se, but the perceptions of the instructor of their role in group work.

\section{THE RESEARCH DESIGN: PHENOMENOGRAPHY}

Taking a phenomenographic approach, the purpose of the research design was to gather a broad range of instructor perceptions. Phenomenography is "a rigorous, empirical exploration of the qualitatively different ways in which people experience and conceptualize various phenomena" (Marton, 2000)(p.103). Trigwell (2000)(p.63) argued that phenomenographers "view that meaning is constituted in the relation between the person and the phenomenon". Phenomenography seeks to represent "all of the data very faithfully" (Walsh, 2000)(p.27) by capturing all of the perceptions, from vague to vivid representations. Phenomenography focuses on the perspective of others, rather than the perspectives of the researcher (Andretta, 2007). Which follows, that the aim of phenomenographic research is not to classify people, or compare groups, or the presentations made by groups, but focuses on conceptions of a phenomenon (Marton, 1981) and represented in a finite number of categories of conceptions. 


\subsection{Research Question}

This study was part of a larger study aimed at examining the perceptions of academics and educational developers about their lived experiences of group work. This paper deals with the central research question, which is stated as:

What are the conceptions of instructors of group work?

\subsection{The Research Participants}

The participants in this research were academics and educational developers employed at fully accredited universities. Metropolitan and regional universities around Australia were represented in this study. All these universities offer on-campus, blended and wholly online graduate courses. In each of their respective employment roles, the research participants are responsible for the development or delivery of a wide variety of higher education courses. Each participant was invited to participate in the research because of their expertise in teaching and learning in virtual learning communities, and more specifically group work. Participants contributed to the research study by way of an online Delphi study, or an online questionnaire and/or a semi-structured face-to-face interview.

\subsubsection{Online Delphi Study}

Nine educational developers participated in the online Delphi study. Over three rounds, participants provided responses to questions and statements relating to group work and online group work

\subsubsection{Online Instructor Questionnaire}

Twenty-one academics participated in the online instructor questionnaire. The online questionnaire consisted of seventeen questions relating to group work and their instructional role. The questions were presented as multiple choice, yes/no, true/false and short answer.

\subsubsection{Semi-Structured Face-to-Face Interviews}

Seventeen semi-structured face-to-face interviews were conducted with academics. Ethics approval to record interviews was granted and recorded interviews were subsequently transcribed verbatim. By using semi-structured face-to-face interviews, the instructors' perceptions of their experiences of group work were sought.

An adapted interview questioning technique of what, why and how (Couger, 1996), supported with prompting strategies (Pitts and Browne, 2007) was implemented. Prior to undertaking the first interview, training using a mock-interview technique was facilitated by the senior and associate researchers. The interview guide consisted of 11 questions. All participants were asked the same questions, with some responses followed up with another question for verification, for example: what did you mean, or, can you provide an example? The motivation for asking a follow-up question was to delve into the instructor's preconceived conception of their specific experience in a specific situation of group work facilitation. Walsh (2000) identified that being sensitive to what the participant is saying, is a means of guiding the research to achieve its' objectives. 


\section{DATA COLLECTION AND ANALYSIS}

Phenomenographers use open, explorative data collection to examine the different ways a phenomenon can be experienced (Cope, 2004). Interviews are the most common means of gathering data in phenomenography (Walsh, 2000). Short-answer text and interview questioning were the predominant means of generating data in this research. The aim of the data collection was to "capture the utterances" of academics relating to group work (Cope, 2004)(p.7). The output space of the research was a set of categories of conception incorporating all the elements that emerged from the analysis. Data analysis commenced during the transcription of the recorded interviews.

\subsection{Data Analysis}

When transcribing the instructor interviews, it was important to be particularly attentive to what the participant had said as a means of revealing the participant's understanding of the phenomenon (Walsh, 2000). Each participant told a different story.

Data analysis in phenomenography is an iterative process, allowing the categories that are in the data to emerge progressively as the repetitions of the data analysis proceeds (Walsh, 2000). As Walsh (2000) contends, in phenomenographic analysis, the discovery is the understanding of particular ways in which the participants describe their experience of the phenomenon.

Each of the particular ways the participant expressed their perspectives of the phenomenon was examined for common, similar and contrasting perceptions. By identifying and recording the common, similar and contrasting perceptions, "a limited number of distinctively different ways of understanding the phenomenon" became evident (Marton, 1994) (p.4425). The common, similar or contrasting perceptions were grouped as categories of conception. Between each of the categories, dimensions of variation were identified. The dimensions of variation show variations of complexity between each of the categories of conception; it is the variation that characterizes the complexity of categories.

Using a phenomenographic research approach facilitated all of the perceptions of the instructors' lived experiences of group work to be captured in a finite set of categories. Each of the categories is separate, yet linked by the means of being common, similar or contrasting perceptions. The dimensions of variation within each of the categories illuminate levels of complexity, which are readily recognised and can be summarised by an aspect of practice (AOP). An AOP is a straightforward way of expressing a summary-descriptor of the category.

\section{RESEARCH FINDINGS}

Analysis of the data revealed six separate, yet linked phenomenographic categories of conception. The six categories of conception found in the data are: Non-Starter; Starter; Co-ordinator; Trusted Advisor; Reflector; and Actuator. Combined the categories of conception describe all of the roles of an instructor in group work. The role descriptors are a means of bringing focal awareness to each of the categories of conception found in the research. The role descriptors are now presented inclusive of AOPs. 


\subsection{Role Descriptors}

\subsubsection{Non-Starter}

Descriptor: relinquisher

This role recognises the value of information and education technology, yet collaborative group work is often relinquished for other forms of learning that deliver the course content as instructor-led learning; the instructor preferring to work with individual students.

AOP: not present

\subsubsection{Starter}

Descriptor: set-and-forget

In this role the instructor prefer to use a minimalist role in the management of group work, preferring to adopt third-party software to manage the process.

AOP: present

\subsubsection{Co-ordinator}

Descriptor: co-ordinates the day-to-day processes of group work

The role of co-ordinator is a minimalist of information management, who prefers to adopt, use and re-use technology-based educational software to manage groups and course content.

AOP: present, responds minimally

\subsubsection{Trusted Advisor}

Descriptor: provides advice, prepared to intervene

The role of a trusted advisor is an instructor who is present, focused, informed, and a proactive user of education technology for instructional-related practices, they are sufficiently confident to intervene in potential issues and provide guidance.

AOP: present, responsive, proactive, a guide

\subsubsection{Reflector}

Descriptor: reflects on processes and outcomes

The reflector uses reflective practice to build their proficiency. This role is informed and can argue for and against the use of group work with the confidence of knowledge. AOP: present, responsive, proactive, aware, reflective, a guide

\subsubsection{Actuator}

Descriptor: able to incite, influence and move others to engage and achieve High levels of motivation for inclusivity and collaboration in online group work are actuated. High levels of expertise of collaboration-based software and its' application are evident. This role demonstrates all of the attributes of the role descriptors.

AOP: enthusiastically present, responsive, proactive, aware, reflective, a guide. 

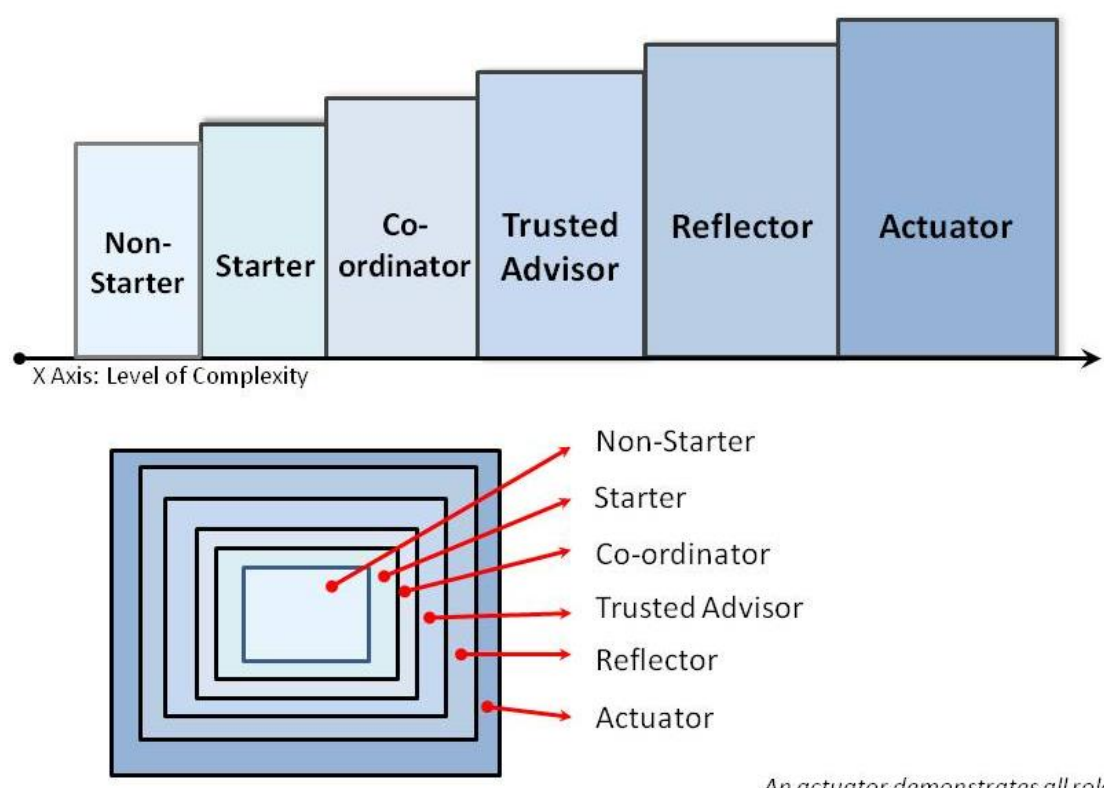

An actuator demonstrates all roles

Figure 2. Categories of Conception

In Figure 2: The Categories of Conception are diagrammatically represented. Individually and collectively these categories represent all the roles of the instructor in group work. The categories can be shown as a hierarchy, from basic to comprehensive. The Non-Starter category is shown at the beginning of the continuum, or core of the hierarchy, moving through to the Actuator category at the higher level. The Actuator category demonstrates all of the roles of the instructor in group work.

\subsection{Dimensions of Variation}

The analysis of the data illuminated the levels of complexity within each of the categories of conception. In phenomenography, the levels of variation that characterize the categories of conception are expressed as dimensions of variation. The four dimensions of variation indentified in the data were: The Instructor Cognition; Group Work Processes; Use of Collaborative ICT; and Reflective Practice. The dimensions of variation found in the data are presented as a hierarchy of simple to complex values, moving from left to right in Table 1: Dimensions of variation. 
Table 1. Dimensions of variation

\begin{tabular}{|c|c|c|c|c|c|c|}
\hline VALUES & $\begin{array}{c}\text { Non- } \\
\text { Starter }\end{array}$ & Starter & $\begin{array}{c}\text { Co- } \\
\text { ordination }\end{array}$ & $\begin{array}{l}\text { Trusted } \\
\text { Advisor }\end{array}$ & Reflector & Actuator \\
\hline $\begin{array}{l}\text { The } \\
\text { Instructor } \\
\text { Cognition }\end{array}$ & $\begin{array}{l}\text { 1a. does not } \\
\text { see the } \\
\text { value of } \\
\text { group work }\end{array}$ & $\begin{array}{l}\text { 1b. unaware } \\
\text { of the full } \\
\text { potential of } \\
\text { group work }\end{array}$ & $\begin{array}{l}\text { 1c. sees the } \\
\text { value and } \\
\text { benefits of } \\
\text { group work }\end{array}$ & $\begin{array}{l}\text { 1d. aware } \\
\text { and } \\
\text { confident of } \\
\text { their role } \\
\text { and } \\
\text { supportive } \\
\text { of students } \\
\text { and other } \\
\text { instructors }\end{array}$ & $\begin{array}{l}\text { 1e. knows } \\
\text { that being } \\
\text { proactive } \\
\text { and } \\
\text { reflective } \\
\text { about group } \\
\text { work } \\
\text { provides the } \\
\text { means to } \\
\text { encourage } \\
\text { others }\end{array}$ & $\begin{array}{l}\text { 1f. realises } \\
\text { their } \\
\text { substantial } \\
\text { expertise is } \\
\text { the key to } \\
\text { influencing } \\
\text { others to } \\
\text { achieve the } \\
\text { group work } \\
\text { objectives }\end{array}$ \\
\hline $\begin{array}{l}\text { Group } \\
\text { Work } \\
\text { Processes }\end{array}$ & $\begin{array}{l}\text { 2a. sees the } \\
\text { processes of } \\
\text { group work } \\
\text { time } \\
\text { consuming }\end{array}$ & $\begin{array}{l}\mathbf{2 b} . \\
\text { recognises } \\
\text { their role as } \\
\text { providing } \\
\text { instruction } \\
\text { and co- } \\
\text { ordination } \\
\text { of the day- } \\
\text { to-day } \\
\text { processes }\end{array}$ & $\begin{array}{l}\mathbf{2 c} \text {. } \\
\text { understands } \\
\text { their role as } \\
\text { a guide, } \\
\text { offering } \\
\text { advice to } \\
\text { individuals } \\
\text { and groups }\end{array}$ & $\begin{array}{l}\text { 2d. knows } \\
\text { and } \\
\text { understands } \\
\text { that } \\
\text { reflection } \\
\text { creates } \\
\text { better } \\
\text { instruction }\end{array}$ & $\begin{array}{l}\text { 2e. knows } \\
\text { that } \\
\text { experience } \\
\text { and being } \\
\text { proactive, } \\
\text { reinforces } \\
\text { good } \\
\text { practice }\end{array}$ & $\begin{array}{l}\text { 2f. realises } \\
\text { that their } \\
\text { knowledge } \\
\text { and } \\
\text { expertise of } \\
\text { group work } \\
\text { can be used } \\
\text { to lead } \\
\text { groups and } \\
\text { other } \\
\text { instructors }\end{array}$ \\
\hline $\begin{array}{l}\text { Use of } \\
\text { Collabora } \\
\text { tive ICT }\end{array}$ & $\begin{array}{l}\text { 3a. } \\
\text { considers } \\
\text { collaborativ } \\
\text { e ICT as } \\
\text { potentially } \\
\text { problematic }\end{array}$ & $\begin{array}{l}\text { 3b. } \\
\text { considers } \\
\text { reliance on } \\
\text { third-party } \\
\text { teamwork } \\
\text { software } \\
\text { most } \\
\text { appropriate }\end{array}$ & $\begin{array}{l}\text { 3c. is } \\
\text { familiar } \\
\text { with a range } \\
\text { of } \\
\text { collaborativ } \\
\text { e software } \\
\text { and chooses } \\
\text { to use } \\
\text { university } \\
\text { preferred } \\
\text { platforms }\end{array}$ & $\begin{array}{l}\text { 3d. } \\
\text { understands } \\
\text { that groups } \\
\text { have access } \\
\text { to a range of } \\
\text { software } \\
\text { platforms } \\
\text { for } \\
\text { collaboration }\end{array}$ & $\begin{array}{l}\text { 3e. knows } \\
\text { the value of } \\
\text { software for } \\
\text { a particular } \\
\text { collaborative } \\
\text { environment }\end{array}$ & $\begin{array}{l}\text { 3f. realises } \\
\text { specific } \\
\text { software } \\
\text { applications } \\
\text { for specific } \\
\text { cohorts }\end{array}$ \\
\hline $\begin{array}{l}\text { Reflective } \\
\text { Practice }\end{array}$ & $\begin{array}{l}\text { 4a. } \\
\text { reflection of } \\
\text { past } \\
\text { experience } \\
\text { of group } \\
\text { work has } \\
\text { reinforced } \\
\text { their } \\
\text { decision not } \\
\text { to offer } \\
\text { group work }\end{array}$ & $\begin{array}{l}\text { 4b. is } \\
\text { minimally } \\
\text { aware that } \\
\text { reflection } \\
\text { can improve } \\
\text { outcomes }\end{array}$ & $\begin{array}{l}\text { 4c. is } \\
\text { minimally } \\
\text { aware that } \\
\text { reflection } \\
\text { can improve } \\
\text { group work } \\
\text { outcomes }\end{array}$ & $\begin{array}{l}\text { 4d. } \\
\text { understands } \\
\text { that their } \\
\text { experience } \\
\text { can be used } \\
\text { to guide } \\
\text { others }\end{array}$ & $\begin{array}{l}\text { 4e. knows } \\
\text { from } \\
\text { experience } \\
\text { that } \\
\text { reflection } \\
\text { builds good } \\
\text { practice }\end{array}$ & $\begin{array}{l}\text { 4f. realises } \\
\text { and } \\
\text { espouses the } \\
\text { benefits of } \\
\text { reflective } \\
\text { practice. }\end{array}$ \\
\hline
\end{tabular}

Table 1: identifies the hierarchy of the dimensions of variation evident through analysis of the data. 


\subsection{Dimensions of Variation Descriptors}

The four dimensions of variation illuminated through analysis of the data can be expressed as descriptors. The descriptors are a means of articulating a range of proficiency within each of the variations. The dimensions of variation descriptors are expressed as:

\subsubsection{The Instructor Cognition}

The Instructor Cognition is the thinking, perception and mindfulness the instructor has about their instructional role in group work. The variation ranges from the basic cognition of the instructor's thoughts that are motivated by the needs of self, to the more comprehensive instructor cognition where their motivation is the success of others.

\subsubsection{Group Work Processes}

Group Work Processes is the dimension of variation that recognises the instructor cognition of group work training. At the lower end of proficiency, the instructor does not provide training on group work processes. At the higher end, comprehensive training is provided as a means of enabling groups to evolve into effective entities.

\subsubsection{Collaborative ICT}

The dimension of variation relating to the use of collaborative software in group work. At the lower end of the dimension of ICT use, the instructor finds collaborative software problematic, preferring not to recommend any particular application. At the higher end, the instructor is able to recommend specific collaborative software applications for specific group projects.

\subsubsection{Reflective Practice}

This dimension of variation recognises reflective practice as an enabler of future practice. At the lower end of the dimension the instructor is not aware of their impact on groups and group work, preferring not to over think their role. At the higher end, the instructor constantly reflects on the impact of their role and uses this reflection to guide future practice.

Individually and collectively these descriptors express the range of variations illuminated by the analysis of the data.

\section{DISCUSSION}

The findings of this research show that the perceptions of instructor's lived experiences of their role in group work can be represented by phenomenographic categories of conception. The categories of conception found in this research are: Non-Starter; Starter; Co-ordinator; Trusted Advisor; Reflector; and Actuator These categories are separate, yet linked by common, similar and contrasting perceptions, even though each of the research participants in this study spoke of very different experiences of group work and online group work.

It can be asserted that instructors of group work are aware of their responsibility to lead and manage the students through the process of group work. Yet the instructors in this study were not specifically aware, or recognised themselves, or identified as a particular category of instructor. More specifically, analysis of the data showed that some instructors were operating 
at the more comprehensive level of actuator. An actuator of group work is someone who has the capacity to influence and move others to engage at an extraordinary level and to enable their groups to achieve a heightened success. Humans can be aware of a specific detail of their experience, and yet not always simultaneously aware of the overall impact of that specific detail (Marton, 2000).

Research into group work has shown that students find working in groups difficult, frustrating and often unproductive for many reasons, one of which is the potential for conflict between group members (Roberts and McInnerney, 2007); (Koh and Hill, 2009); (Smith et al., 2011). Research has also shown that online group work is just too difficult to manage (Chang, 2018). Urhahne et al. (2010) found that the role of the instructor in computer-supported collaborative enquiry was task based which can be articulated as the 5E Model. The 5E Model principles are: Envision; Enable; Encourage; Ensure; and Evaluate.

Whereas, by examining the perceptions of the instructors' lived experiences of group work it can be shown that instructors perceive their role differently. The findings of this research resonate with Arbaugh (2008), the role of the instructor cannot be understated, it is a role that goes beyond the contention that in an online environment the instructor simply transitions from "knowledge disseminator to that of interaction facilitator" (p.1236).

By understanding the perceptions of instructors of their role of group work, then ways can be found to increase the use of group work in online courses. Only by understanding the instructor perceptions can individual behaviours be understood and modified. Actions are based on the perceptions of the world are formed by lived experience. Mimirinis (2019) revealed that changes in academics' conceptions are essential to enact changes in practice.

One strategy to change practice, and to move instructors along the hierarchy of categories, one category at a time, is awareness. The challenge for the future then is to engender a change in the practice of online group work. Disseminating the findings of this research is one such means of creating an awareness for the instructor about their ways of "seeing, understanding and experiencing" (Wright and Osman, 2018)(p.260) their role in group work.

\section{CONCLUSION}

At the outset it was introduced that group work facilitates collaborative learning and is widely recognised by employers as preparation for teamwork, yet research has established that online group work is not widely practiced. By using phenomenography this research aimed to examine patterns of instruction in group work and online group. The findings show that the role of the instructor is identified as six categories of conception. The six categories of conception are: Non-Starter; Starter; Co-ordinator; Trusted Advisor; Reflector; and Actuator.

By creating an awareness, or collective consciousness for the instructor, it is possible to open each instructor up to the next level in the hierarchical categories of conception, and in turn improve group work proficiency. Marton and Booth (1997) depict the nature of awareness as a framework where the person's awareness is implied by their understanding, whilst being aware of certain parts of the situation, or phenomenon, and only tacitly aware of other parts. Further, that a phenomenon is understood through the situation in which it occurred, and yet our experience can be modified, transformed and developed by focusing on the situation (Marton and Booth, 1997). 
IADIS International Journal on WWW/Internet

Earlier, the role of Non-Starter was described as a relinquisher of group work. The analysis of the data showed that the Non-Starter had made a conscious decision not to offer group work, preferring to work with individual students. By creating an awareness, or collective consciousness for the need of instructor-responsibility, it is contended that it is possible to move the Non-Starter to the higher category of conception of Starter.

Similarly, to move the Co-ordinator to the Trusted Advisor category, it would be necessary to promote the awareness of being engaged in the group work situation, to be confident of their role and be willing to provide comprehensive instruction. To move to the next higher category of conception of Reflector, the benefits of reflexive practice would need to be shown. Lastly, an Actuator of group work was found to be an instructor who animates, inspires and stimulates groups to become high achieving entities. To move to the Actuator category it would be necessary to create an awareness or collective consciousness, to be an instructor who is aware of their innate ability to incite, influence and move others to engage and achieve.

It is concluded, by raising the awareness, or collective consciousness of the instructor in their role, that an improvement in the proficiency and uptake of online group work can be achieved.

\section{REFERENCES}

An, H., Kim, S. \& Kim, B. 2008. Teacher Perspectives on Online Collaborative Learning: Factors Perceived as Facilitating and Impeding Successful Online Group Work. Contemporary Issues in Technology and Teacher Education, 8(1), 65-83.

Andretta, S. 2007. Phenomenography: a conceptual framework for information literacy education. Aslib Proceedings: New Information Perspectives, 59, 152-168.

Arbaugh, J. B. 2008. Instructors as Facilitators of Learner-Learner Interaction in Third-Generation Learning Environments. Industrial and Organizational Psychology, 1, 487-490.

Arbaugh, J. B. 2010. Sage, guide, both, or even more? An examination of instructor activity in online MBA courses. Computers and Education, 1234-1244.

Barcelona, R. J. \& Rockey, D. L. J. 2010. Using Collaborative Learning Technologies to Facilitate Effective Group Work. JOPERD, 81.

Baskin, C., Barker, M. \& Woods, P. 2005. When group work leaves the classroom does group skills development also go out the window? British Journal of Educational Technology, 36, 19-31.

Bigatel, P. M., Ragan, L. C., Kennan, S., May, J. \& Redmond, B. F. 2012. The identification of competencies for online teaching success. Journal of Asynchronous Learning Networks, 16.1, 59.

Chang, B. 2018. Active Knowledge Sharing in Online Group Work. New Horizons in Adult Education \& Human Resource Development, 30(3), 41-59.

Chang, B. \& Kang, H. 2016. Challenges facing group work online. Distance Education, 37:1, 73-88.

Choi, H. \& Kang, M. 2010. Applying an activity system to online collaborative group work analysis. British Journal of Educational Technology, 41, 776-795.

Cope, C. 2004. Ensuring validity and reliability in phenomenographic research using the analytical framework of a structure of awareness. Qualitative Research Journal, 4, 5-18.

Couger, J. D. 1996. Creativity and Innovation in Information Systems Organizations, Danvers, MA. USA, Boyd and Fraser Publishing Co.,.

Davey, B., Bozan, K., Houghton, R. \& Parker, K. 2016. Alternatives for Pragmatic Responses to Group Work Problems. Informing Science: the International Journal of an Emerging Transdiscipline, 19 89-102. 
Friedman, H. H. \& Friedman, L. W. 2011. Crises in Education: Online Learning as a Solution. Creative Education, 2, 156-163.

Goold, A., Coldwell, J. \& Craig, A. 2010. An examination of the role of the e-tutor. Australasian Journal of Educational Technology, 26(5), 704-716.

Hase, S. K., C. 2001. From Andragogy to Heutagogy. Peered reviewed journal - Southern Cross Universit.

Kavanagh, L., Harrison, J., Cokley, J. \& Neil, D. 2010. Proactively Ensuring Team Success (The PETS Process). A Guide to Effective Student Project Teams in Higher Education. Australia: The University of Queensland.

Koh, M. H. \& Hill, J. R. 2009. Student Perceptions of Group Work in an Online Course: Benefits and Challenges. Journal of Distance Education, 23, 69-92.

Kraiger, K. 2008. Third-Generation Instructional Models: More About Guiding Development and Design Than Selecting Training Methods. Industrial and Organizational Psychology, 1, 501-507.

Laurillard, D. 2012. Teaching as a Design Science, New York and London, Routledge.

Marton, F. 1981. Phenomenography - Describing Conceptions of the World Around Us. Instructional Science, 10, 177-200.

Marton, F. 1994. Phenomenography. In: Husen, T. \& Postlethwaite, T. N. (eds.) The International Encyclopedia of Education. Second ed. Oxford, England: Elsevier Science Ltd.

Marton, F. 2000. The structure of awareness. In: Bowden, J. A. \& Walsh, E. (eds.) Phenomenography. Melbourne: RMIT University Press.

Marton, F. \& Booth, S. 1997. Learning and Awareness, Mahway, New Jersey 07430, Lawrence Erlbaum Associates.

Mimirinis, M. 2019. Qualitative differences in academics' conceptions of e-assessment. Assessment \& Evaluation in Higher Education, 233-248.

Oliveira, I., Tinoca, L. \& Pereira, A. 2011. Online group work patterns: How to promote a successful collaboration. Computers \& Education, 57, 1348-1357.

Pitts, M. G. \& Browne, G., J. 2007. Improving requirements elicitation: an empirical investigation of procedural prompts. Info Systems Journal, 17, 89-110.

Riebe, L., Girardi, A. \& Whitsed, C. 2016. Teaching teamwork skills in Australian higher education business disciplines. 25th Annual Teaching Learning Forum. Perth, Australia: Curtin University.

Rienties, B., Brouwer, N. \& Lygo-Baker, S. 2013. The effects of online professional development on higher education teachers' beliefs and intentions towards learning facilitation and technology. Teaching and Teacher Education, 29, 122-131.

Roberts, T. M. \& Mcinnerney, J. M. 2007. Seven Problems of Online Group Learning (and Their Solutions). Educational Technology \& Society, 10(4), 257-268.

Salmon, G., Gregory, J., Lokuge Dona, K. \& Ross, B. 2015. Experiential online development for educators: The example of the Carpe Diem MOOC. British Journal of Educational Technology, 46, $542-556$.

Smith, G. G., Sorensen, C., Gump, A., Heindel, A. J., Caris, M. \& Martinez, C. D. 2011. Overcoming student resistance to group work: Online versus face-to-face. Internet and Higher Education, 14 121-128.

Trigwell, K. 2000. A phenomenographic interview on phenomenography. In: Bowden, J. A. \& Walsh, E. (eds.) Phenomenography. Melbourne: RMIT University Press.

Urhahne, D., Schanze, S., Bell, T., Mansfield, A. \& Holmes, J. 2010. Role of the Teacher in Computer-supported Collaborative Inquiry Learning. International Journal of Science Education, 32:2, 221-243.

Walsh, E. 2000. Phenomenographic analysis of interview transcripts. In: Bowden, J. A. \& Walsh, E. (eds.) Phenomenography. Melbourne, Australia: RMIT University Press.

Wilson, K. J., Brickman, P. \& Brame, C. J. 2018a. Group Work. CBE Life Science Education, 17. 
IADIS International Journal on WWW/Internet

Wilson, K. J., Brickman, P. \& Brame, C. J. 2018b. Group Work. CBE - Life Sciences Education, 17:fel, $1-5$.

Wright, E. \& Osman, R. 2018. What is critical for transforming higher education? The transformative potential of pedagogical framework of phenomenography and variation theory of learning for higher education. Journal of Human Behavior in the Social Environment, 28:3, 257-270.

Xu, J., Du, J. \& Fan, X. 2015. Students' Groupwork Management in Online Collaborative Learning Environments. Journal of Educational Technology \& Society, 18 (2), 195-205.

Young, S. 2006. Student Views of Effective Online Teaching in Higher Education. The American Journal of Distance Education, 20(2), 65-77. 